\title{
SDF-1 gene polymorphism and CCL3L1 gene copy number and susceptibility to HIV-1 / AIDS among Indians
}

Suhani Almal, Anuroopa Gupta, Harish Padh ${ }^{*}$

From First International Science Symposium on HIV and Infectious Diseases (HIV SCIENCE 2012)

Chennai, India. 20-22 January 2012

\section{Background}

Stromal derived factor $(S D F-1)$ is a natural ligand for CXCR4 and chemokine (C-C) motif ligand 3-like 1 (CCL3L1) is for CCR5 HIV coreceptors. The individual role of the SNP in 3' untranslated region of SDF-1 (SDF1-3'A) and low copy number of the CCL3L1 gene in determining susceptibility to HIV infection is well documented. The aim of the present study was to analyze the synergistic effect of the SNP in $S D F-1$ gene and CNV in CCL3L1 gene influencing the susceptibility to HIV-1/AIDS in Indians.

\section{Methods}

This study involved the assessment of 105 healthy control individuals and 44 HIV-1 patients for the SDF-1 gene polymorphism by PCR-restriction fragment length polymorphism (RFLP) and CCL3L1 gene copy number $(\mathrm{CN})$ by real-time PCR.

\section{Results}

In order to assess the synergistic effect of the SDF1-3'A polymorphism and CCL3L1 CN, SDF1-3'A allele and CCL3L1 $\geq 2$ copies conferring a protection to HIV-1 were considered as reference combination. The odds ratio (OR) was 0.97 (95\% CI -0.30 to $3.13 ; p=0.597$ ) for SDF1-3'A, CCL3L1 $\leq 2$ copies, 0.73 (95\% CI - 0.23 to $2.33 ; p=0.408)$ for SDF1, CCL3L1 > 2 copies and 0.93 (95\% CI -0.327 to $2.703 ; p=0.555$ ) for SDF1-3'A, CCL3L1 $\leq 2$ copies combinations as compared to SDF13'A, CCL3̄L $1 \geq 2$ copies.

\footnotetext{
* Correspondence: hpadh@yahoo.com

Department of Cellular and Molecular Biology, B. V. Patel Pharmaceutical Education and Research Development (PERD) Centre, Ahmedabad, India
}

\section{Conclusion}

Our analyses suggest that a combination of SDF1-3'A and lower copy number of CCL3L1 do not provide any discernible synergistic protection from HIV-1 infection.

Published: 4 May 2012

doi:10.1186/1471-2334-12-S1-P50

Cite this article as: Almal et al:: SDF-1 gene polymorphism and CCL3L1 gene copy number and susceptibility to HIV-1 / AIDS among Indians. BMC Infectious Diseases 2012 12(Suppl 1):P50.
Submit your next manuscript to BioMed Central and take full advantage of:

- Convenient online submission

- Thorough peer review

- No space constraints or color figure charges

- Immediate publication on acceptance

- Inclusion in PubMed, CAS, Scopus and Google Scholar

- Research which is freely available for redistribution

\section{Biomed Central}

